\title{
The Relationship between Air Pollution, Economic Growth, and Life Expectancy: Empirical Evidence from Indonesia
}

\author{
Abdul Bashir ${ }^{1}$, Liliana ${ }^{2}$, Ariodillah Hidayat ${ }^{3}$, Suhel ${ }^{*}$ \\ 1,2,3,4Faculty of Economics, Universitas Sriwijaya, Indonesia \\ E-mail: ${ }^{1}$ abd.bashir@fe.unsri.ac.id, ${ }^{2}$ liliana@unsri.ac.id, \\ 3ariodillahhidayat@fe.unsri.ac.id, ${ }^{4}$ suhel@fe.unsri.ac.id \\ "Corresponding author
}

JEL Classification:

I15

Q53

O44

Received: 27 November 2021

Revised: 07 December 2021

Accepted: 30 December 2021

\begin{abstract}
This study investigates the relationship between air pollution, economic growth, and life expectancy in Indonesia. The observation period during 1985-2019 used time-series data obtained from the World Bank. Quantitative approach by applying two main models, namely the autoregressive distributed lag (ARDL) model by considering the effect of time-lapse and Granger causality with vector error correction method. Research findings prove that air pollution has a negative effect on life expectancy in the long run. Economic growth has a positive effect on life expectancy. In the short run, the current life expectancy is positively influenced by the life expectancy of the previous period. Air pollution has a negative effect on life expectancy, and economic growth has a negative effect on life expectancy. Another finding in the Granger causality model is a two-way relationship between air pollution and life expectancy. Other evidence exists of a two-way relationship between economic growth and air pollution. In addition, evidence of a unidirectional relationship of economic growth with life expectancy in the short run. The cointegration equation shows evidence of a long-run relationship between air pollution, economic growth, and life expectancy.
\end{abstract}

\section{Keywords:}

Air pollution, Causality, Economic growth, Life expectancy, ARDL

How to Cite:

Bashir, A., Liliana, L., Hidayat, A., Suhel, S., Hamidi, I., \& Atiyatna, D. P. (2022). The Relationship between Air Pollution, Economic Growth, and Life Expectancy: Empirical Evidence from Indonesia. Signifikan: Jurnal IImu Ekonomi, 11(1), 125-144. https://doi.org/10.15408/sjie.v11i1.23334. 


\section{INTRODUCTION}

The relationship between air pollution and human health is still an exciting topic debated by experts. Air pollution due to greenhouse gas (GHG) emissions is still a significant problem in several regions of the world, including Indonesia, because it is possible to hinder sustainable development (Olivier et al., 2016). The significant increase in the effect of greenhouse gases that have been felt during the last decade has caused global warming, so this is a concern for various parties in the world because it is considered to be a threat to human life in the future (De Sherbinin et al., 2007; Fauzi, 2017; Harris et al., 2017). The concern of many parties in the world is also getting more significant for the environment, such as the Paris Agreement on the policy framework in suppressing the occurrence of climate change by reducing pollution emissions. This effort was initiated by the United Nations Framework Convention on Climate Change (UNFCCC). The treaty was ratified by 147 countries and entered into force in 2016.

Indications of global warming can be felt from the increase in the earth's average temperature due to the induction of GHG effects in the atmosphere, mainly caused by human activities (Fauzi, 2017; Misra, 2014; Patz et al., 2003). In addition to global warming, other possible effects of increased greenhouse gases could include increased acid rain and smog-filled cities, all of which can have harmful effects on human health. (Manisalidis et al., 2020; Perrino et al., 2020). However, it can also be said that countries produce a large amount of greenhouse gas emissions due to industrialization and large energy consumption, which encourages economic growth as most individuals will spend more on social security and health care which may have a negative effect. Desirable on each individual's health (Anil Cabraal et al., 2005; Kaygusuz, 2007). Although greenhouse gas emissions harm the biosphere and human health, they can also accelerate economic growth, allowing individuals to spend their money on health care. (Parrique et al., 2019). On the other hand, improving air quality can positively impact health and promote economic growth (Jiang et al., 2020; Selden \& Song, 1994, 1995). Increasing healthy lifestyles and caring for the environment will benefit air quality and encourage economic growth (Mansor \& Harun, 2014; Schraufnagel et al., 2019; Selden \& Song, 1994).

This study refers to several recent studies on the relationship between economic growth, pollution, and life expectancy conducted by Ebenstein et al. (2015), Kunze (2014), and Jiang et al. (2020) found that there is a strong positive relationship between GDP and life expectancy. A doubling of income is expected to increase life expectancy, but in the absence of policy innovation, the relationship between the two is an inverted U-shape. Studies conducted by Sharma (2018) and Biyase \& Maleka (2019) found that life expectancy, democracy, and the population had the expected positive impact on economic growth. The study by Cervellati \& Sunde (2011); Rjoub et al. (2021); Ngangue \& Manfred (2015), and $\mathrm{He} \& \mathrm{Li}$ (2019) found a positive movement between life expectancy and economic growth in a study in several developed and developing countries (Bashir et al., 2019). The results are robust to address the possible reverse causality between life expectancy and economic growth. 
Additionally, related studies on the relationship between life expectancy and pollution have been carried out by Mariani et al. (2010); Agbanike et al. (2019); Kelly (2017); and Lelieveld et al. (2020) found that there is a positive correlation between life expectancy and environmental quality, both in the long-run and along the transition path. These results are consistent with life expectancy and environmental performance measures. In contrast, the impact of air pollution on life expectancy is negative and more robust in the long run. The available study on this topic is relatively limited because previous population-based studies have been based on the relationship between air pollution, population size, and income (Bashir et al., 2021; Biyase \& Maleka, 2019; Carson et al., 1997; Ghanem, 2018; Jiang et al., 2020; Okunade \& Osmani, 2020). Additionally, studies on the topic of the relationship between air pollution and relative mortality rates can also be found Cesur et al. (2017) and Dholakia et al. (2014). Analysis of mortality data requires a time series model to account for daily variations in pollution and the number of deaths. However, the use of time series models for this type of data is that the results can be biased from factors such as temperature and influenza epidemics, which are prone to variation over short periods (Goenka et al., 2012). Consequently, more recent studies have analyzed the relationship between air pollution and life expectancy as a measure of overall public health, as annual comparisons aggregate life expectancy.

This study focuses on the causal effects of air pollution, health, and spatial economic growth in Indonesia. This country has the largest archipelagic country globally and covers an area of almost 2 million square kilometers and in 2018 had a population of around 267 million. In 2019 it was ranked the 6th most polluted country out of 98 competitors worldwide. The average Air Quality Index (AQI) in 2019 was 141 with a PM2.5 level or has reached five times the exposure recommendation of the World Health Organization (WHO). The source of air pollution in Indonesia comes from forest fires. During October 2015, nearly 5,000 fires co-occurred in forests and peatlands. In just one day, about 80 million metric tons of carbon dioxide $\left(\mathrm{CO}_{2}\right)$ are generated, or five times more than the United States economy as a whole. The remaining pollution generated by the transportation sector, energy production by industry, and emissions from coal-fired power plants is increasing rapidly on the west side of the island of Java, intending to meet increasing public demand.

The relationship between air quality, life expectancy, and economic growth is still exciting to debate. The findings of this study are expected to provide essential insights and discussion material for policymakers about mitigating the impact of air on health and vice versa its benefits on economic growth. Additionally, the available studies on this topic are still relatively limited, especially in some developing countries such as Indonesia. Therefore, this study will examine the relationship between air quality as an indicator of greenhouse gas emissions, life expectancy as an indicator of the average number of years the population can live (human health), and economic growth as an indicator of increasing income per capita. Pollution is one of the problems faced by several regions in the world and has not been handled in Indonesia. The speed of decline in air quality 
in several big cities in Indonesia has been seen in the last few decades, as evidenced by the monitoring data on particle parameters (PM10, PM2.5) and oxidant/ozone (O3), which tend to increase. Improvements in infrastructure such as roads also encourage transportation equipment to increase and increase the population.

A healthy lifestyle reflects concern for the environment, and if humans maintain health in their lifestyle, it also means maintaining the environment and the cleanliness of the air around them. A healthy lifestyle and pristine air quality will benefit the economy because each individual will produce goods and services or work for life. Therefore, there are two studies formulated in this study, namely: (1) how to empirically prove the effect of life expectancy as a proxy for health indicators and economic growth as a proxy for increasing per capita income on air quality in Indonesia both in the short and long-run; and (2) what are the results of proving the relationship between air quality, life expectancy, and economic growth in Indonesia, both in the short and long-run.

\section{METHODS}

The scope of this research is to look specifically at the short-run and long-run effects of increasing air pollution and growth on health. In addition, this study also looks at the empirical relationship between investigating relationship between air pollution, economic growth, and life expectancy. The data used in this study is time-series data with an observation period of 1985-2019. In addition, this study also uses secondary data obtained from the World Bank. Air pollution data is proxied from $\mathrm{CO}_{2}$ emissions, life expectancy is proxied from the average age of the population in years, and economic growth is proxied from GDP per capita in US dollars.

Table 1. Data and Source

\begin{tabular}{cccc}
\hline Variable & Descriptions & Unit measurement & Source \\
\hline $\mathrm{CO}_{2}$ & Air pollution $\left(\mathrm{CO}_{2}\right.$ emissions) & Kiloton per capita & World Bank \\
GDP & Real GDP per capita & US\$, constant 2010 & World Bank \\
LE & Life expectancy & Year & World Bank \\
\hline
\end{tabular}

The operational definitions of the variables used in this study are:

(1) Air pollution $\left(\mathrm{CO}_{2}\right)$ is a condition of the concentration level of pollutants contained in the air. Air pollutants that significantly affect human life are proxied from carbon dioxide emissions $\left(\mathrm{CO}_{2}\right.$ emission $)$ data.

(2) Life expectancy (LE) estimates the average length of life of a population with the assumption that there is no change in the pattern of mortality (death) according to age in an area over a certain period. The indicator is a measure of the population's ability to survive longer. Life expectancy is strongly influenced by physical health, income, and environmental security. 
(3) Economic growth (GDP) is a condition in which there is an increase in the production of goods and services, followed by an increase in people's income in an area proxied from real GDP per capita in a certain period.

\section{Model Specification}

This study uses a quantitative approach by applying two main models: the autoregressive distributed lag (ARDL) model and the vector error correction causality model (VECM). However, before applying the model, a statistical testing stage is required. This is done to apply the two models above to produce valid estimates. To get good estimation results, several stages of statistical testing are needed. The testing stages are: (1) unit root test (stationary) to ensure that the data used has a stable trend; (2) the selection of the optimum lag criteria to give meaning to the dynamics of the variables in the model equation; (3) cointegration test to see the long-run equilibrium relationship between independent variables which, although individually, are not stationary; (4) normal test to see whether the residual variable generated by the regression model has a normal distribution or not with the Jarque-Bera test (JBtest); (5) multicollinearity test to ensure that there is no perfect or definite linear relationship; (6) autocorrelation test to ensure that the estimated residual variance is not too low from the actual; and (7) heteroscedasticity test to ensure that the variance of the residual term is unstable in each observation.

\section{The Auto-regressive Distributed Lag Model}

The autoregressive distributed lag model is one of the econometric approaches involving time-series data. If the regression model includes variable values that explain the current endogenous variables and past values (lagged), the model formed is called a distributed lagged model. -lag-model). In addition, the ARDL model is also formed by entering one or more past values (lagged) from exogenous variables to explain endogenous variables. The model formed is called the autoregressive (AR) model. In economics, the dependence of an endogenous variable on an exogenous variable is rarely instantaneous. Exogenous variables often react to endogenous variables with a time interval (lagged). The equations for the autoregressive distributed lag model that will measure the alleged effects of short-run adjustments towards a long-run balance of life expectancy and economic growth on air quality in each region in Indonesia are generally presented as follows:

$$
\begin{aligned}
\Delta \operatorname{lnLE} E_{\mathrm{t}}= & \alpha_{0}+\sum \alpha_{1} \Delta \operatorname{lnLE}_{\mathrm{t}}+\sum \alpha_{2} \Delta \operatorname{lnGDP}_{\mathrm{t}}+\sum \alpha_{3} \Delta \operatorname{lnCO}_{\mathrm{t}}+\alpha_{4} \Delta \operatorname{lnLE}_{\mathrm{t}-1}+ \\
& \alpha_{5} \Delta \operatorname{lngRDP}_{\mathrm{t}-1}+\alpha_{6} \Delta \operatorname{lnCO}_{\mathrm{t}-1}+\alpha_{7} \Delta \mathrm{ECM}_{\mathrm{t}-1}+\varepsilon_{\mathrm{t}}
\end{aligned}
$$

Where: $\operatorname{lnCO} 2$ is air pollution $\left(\mathrm{CO}_{2}\right.$ emissions in kilotons per capita); lnLE is life expectancy (years); lnGDP is economic growth (real GDP per capita in dollars, constant, 2010); $t$ is th7e time series (period 1985-2019); $\alpha_{0}$ is intercept; $\alpha_{1}, \alpha_{2}, \alpha_{3}, \alpha_{4}, \alpha_{5}, \alpha_{6}$ is the parameter coefficient of each exogenous variable and $\varepsilon_{t}$ is residual. 


\section{The Vector Error Correction Model Granger Causality}

A method for building a model of causality between economic variables in a nonstructural manner. The methods are vector autoregressive (VAR) and vector error correction models (VEC). The VAR model was created based on the statistical properties of the data. In the VAR model, each endogenous variable in the system is considered a lagged value of all endogenous variables; thus, an autoregressive model in a univariate system is generalized to a "vector" autoregressive model consisting of a " vector " autoregressive model of time series variables in a multivariate system.

Engle \& Granger (1987) combines cointegration and error correction models to establish a vector error correction model. According to him, the VEC model is more valid in measuring the level of relationship between cointegrated variables. This means that as long as there is a cointegration relationship between variables, the vector error correction model can be derived from the autoregressive distributed lag model. Each equation in the VAR model is an autoregressive distributed lag model. Thus, the VEC model is a VAR model with cointegration constraints. Since there is a cointegration relationship in the VEC model, when there are many short-run dynamic fluctuations, VEC expression can limit the long-run behavior of the endogenous variables and become convergent with their cointegration relationship (Zou et al., 2018, 2020). The equations of the causality model for vector fatigue correction in the study are presented as follows:

$$
\begin{aligned}
& \Delta \operatorname{lnLE}_{\mathrm{t}}=\alpha_{0}+\sum \alpha_{1} \Delta \operatorname{lnLE}_{\mathrm{t}-\mathrm{i}}+\sum \alpha_{2} \Delta \operatorname{lnGDP}_{\mathrm{t}-\mathrm{i}}+\sum \alpha_{3} \Delta \operatorname{lnCO} 2_{\mathrm{t}-\mathrm{i}}+\alpha_{4} \mathrm{ECT}_{\mathrm{t}-1}+ \\
& \varepsilon_{2 \mathrm{t}} \\
& \Delta \operatorname{lnCO} 2_{\mathrm{t}}=\alpha_{0}+\sum \alpha_{1} \Delta \operatorname{lnLE} \mathrm{E}_{\mathrm{t}-\mathrm{i}}+\sum \alpha_{2} \Delta \operatorname{lnGDP}_{\mathrm{t}-\mathrm{i}}+\sum \alpha_{3} \Delta \operatorname{lnCO} 2_{\mathrm{t}-\mathrm{i}}+\alpha_{4} \mathrm{ECT}_{\mathrm{t}-1}+ \\
& \varepsilon_{1, \mathrm{t}} \\
& \Delta \operatorname{lnGDP} P_{\mathrm{t}}=\alpha_{0}+\sum \alpha_{1} \Delta \operatorname{lnLE}_{\mathrm{t}-\mathrm{i}}+\sum \alpha_{2} \Delta \operatorname{lngDP}_{\mathrm{t}-\mathrm{i}}+\sum \alpha_{3} \Delta \operatorname{lnCO}_{\mathrm{t}-\mathrm{i}}+\alpha_{4} \mathrm{ECT}_{\mathrm{t}-1}+ \\
& \varepsilon_{3 \mathrm{t}}
\end{aligned}
$$

Where: $\operatorname{lnCO} 2$ is air pollution $\left(\mathrm{CO}_{2}\right.$ emissions in kilotons per capita); $\operatorname{lnLE}$ is life expectancy (years); lnGDP is economic growth (real GDP per capita in dollars, constant, 2010); $t$ is the time series (period 1985-2019); $\alpha_{0}$ is intercept; $\alpha_{1}, \alpha_{2}, \alpha_{3}, \alpha_{4}, \alpha_{5}, \alpha_{6}$ is the parameter coefficient of each exogenous variable and $\varepsilon_{t}$ is residual; ECT th $_{1}$ is the vector error correction coefficient (short-run adjustment towards long-run equilibrium); $\varepsilon_{\mathrm{t}}$ is residual.

\section{RESULT AND DISCUSSION}

The development of carbon dioxide emissions in Indonesia currently shows a fluctuating trend, carbon dioxide emissions produced by Indonesia in 2019 have reached 632 million tons. This number increased from the previous year of 581 million tons or grew by 8.85 percent. During the 1985-2019 growth in carbon dioxide emissions increased by 6.09 percent. This increase in carbon dioxide emissions is also in line with 
the economic growth rate in Indonesia, which is 6.31 percent during the same period. Most of Indonesia's carbon dioxide emissions come from illegal or licensed logging and peat forest fires that always occur during the dry season (Santika et al., 2017). In addition, carbon dioxide emissions are also produced from burning fossil fuels for energy in the industrial, manufacturing, and transportation sectors, which can also directly encourage the growth of other economic sectors.

Life expectancy in Indonesia during 1985-2019 shows a fluctuating trend throughout the year (Figure 1). During the study period, growth in life expectancy reached 0.51 percent, with an average of 66.39 years. It is undeniable that public health in Indonesia still needs serious attention. The slowing growth in life expectancy is caused by high air pollution. Meanwhile, per capita income growth in 2019 was US\$ 4,136, and this figure increased from the previous year of 6.21 percent.

Figure 1. Trends in $\mathrm{CO}_{2}$ Emissions, Life Expectancy, and Economic Growth

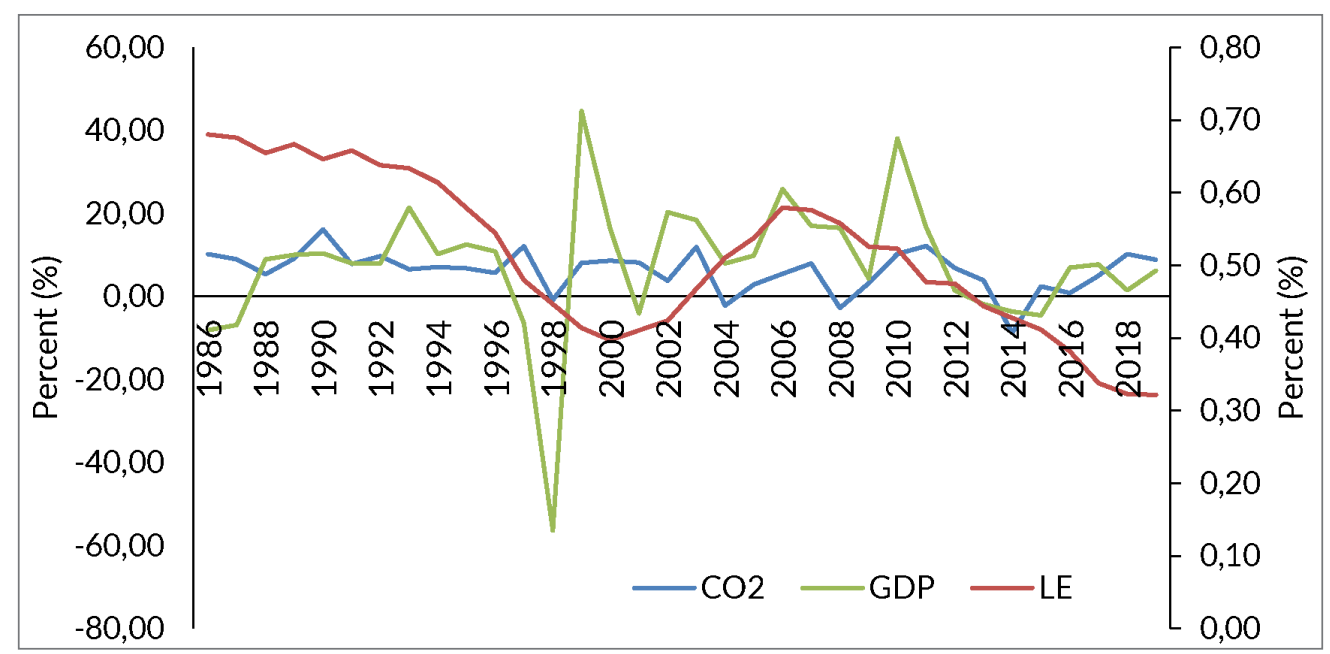

The development of economic growth seen from per capita income (purchasing power parity) from 1985 to 2019 showed a fluctuating trend. The growth of income per capita during the study period was 6.31 percent. The main factor driving Indonesia's economic growth is domestic demand, especially household consumption, investment, and government consumption. However, during the last five years, Indonesia's economic growth has slowed. This is related to the relatively limited export performance in line with the trend of weakening world trade due to increasing pressure originating from external turmoil.

Table 2 reports the statistical description of research data for each variable, according to the results of the descriptive statistics implying that the variables' central tendency is relatively good. The standard deviation results show a relatively small value, implying that the standard deviation or dispersion is still relatively average. Meanwhile, the skewness value indicates that the size of the data used in the distribution of values is symmetrical, then the kurtosis value indicates that the degree of tailedness is lower 
than 3, so the data in this study is platykurtic. The results of the Jarque-Bera test also show that the data in the study are relatively normally distributed. The observation period is 35 years.

Table 2. Descriptive Statistics

\begin{tabular}{|c|c|c|c|}
\hline Descriptive & InLE & $\mathrm{InCO}_{2}$ & InGDP \\
\hline Mean & 4.194 & 5.599 & 7.169 \\
\hline Median & 4.194 & 5.710 & 6.971 \\
\hline Maximum & 4.273 & 6.449 & 8.327 \\
\hline Minimum & 4.099 & 4.439 & 6.092 \\
\hline Std. Dev. & 0.052 & 0.583 & 0.774 \\
\hline Skewness & -0.161 & -0.437 & 0.228 \\
\hline Kurtosis & 1.873 & 2.036 & 1.576 \\
\hline Jarque-Bera & 2.004 & 2.467 & 3.258 \\
\hline Probability & 0.367 & 0.291 & 0.196 \\
\hline Sum & 146.797 & 195.974 & 250.918 \\
\hline Sum Sq. Dev. & 0.092 & 11.588 & 20.390 \\
\hline Observations & 35 & 35 & 35 \\
\hline \multicolumn{4}{|l|}{ Correlation } \\
\hline $\operatorname{lnLE}$ & 1.000 & & \\
\hline $\mathrm{InCO}_{2}$ & 0.591 & 1.000 & \\
\hline InGDP & 0.439 & 0.610 & 1.000 \\
\hline
\end{tabular}

Source: Author calculations

The results of the diagnosis of the relationship matrix between independent variables indicate that the relationship matrix between independent variables in this study has medium and low categories. Thus, this research model does not have symptoms of statistical multicollinearity assumptions, which means the research model can be continued to the next estimation stage.

\section{Unit root test}

Testing the feasibility of the data is done by identifying whether the time series data used has stability in the observed period, such as the average, variance, and covariance of the independent variables that are not entirely influenced by time.

The results of the stationary test on the variables presented in Table 3 show that in the level stage test, all variables contain a unit root, which means it is not stationary, meaning that at the level stage, the variables in this study cannot be continued in the next estimation stage. Based on the 5 percent alpha value in the first difference test, all 
variables do not contain unit-roots. Thus, the variables used in the study are at the first differences stage. It is concluded that the time series data used is stationary.

Table 3. Unit Root test

\begin{tabular}{|c|c|c|c|c|c|}
\hline \multirow{3}{*}{ Variable } & \multicolumn{5}{|c|}{ Unit root test } \\
\hline & \multirow{2}{*}{$\begin{array}{c}\text { Critical } \\
\text { value (\%) }\end{array}$} & \multicolumn{2}{|c|}{ level } & \multicolumn{2}{|c|}{$1^{\text {st }}$ differences } \\
\hline & & t-stat & ADF-test & t-stat & ADF-test \\
\hline \multirow{3}{*}{ InLE } & $1 \%$ & -3.661 & & -2.639 & \\
\hline & $5 \%$ & -2.960 & -2.851 & -1.951 & $-2.767^{* * *}$ \\
\hline & $10 \%$ & -2.619 & & -1.610 & \\
\hline \multirow{3}{*}{ InCO2 } & $1 \%$ & -3.639 & & -3.646 & \\
\hline & $5 \%$ & -2.951 & -2.448 & -2.954 & $-4.808^{* * *}$ \\
\hline & $10 \%$ & -2.614 & & -2.615 & \\
\hline \multirow{3}{*}{$\operatorname{lnGDP}$} & $1 \%$ & -3.639 & & -3.646 & \\
\hline & $5 \%$ & -2.951 & -0.399 & -2.954 & $-5.861^{* * *}$ \\
\hline & $10 \%$ & -2.614 & & -2.615 & \\
\hline
\end{tabular}

Note: ${ }^{* * *} 1 \%,{ }^{* *} 5 \%,{ }^{*} 10 \%$ at significant level

\section{Lag Order Selection Criteria}

Determining the optimal lag criteria in this research model is essential because choosing an adequate lag length for each variable can give meaning to the dynamics of the variables in the model equation. Bahmani-Oskooee \& Brooks (2003) determining the optimal lag length can use one of the information criteria from the Akaike information criterion (AIC) and Schwarz information criterion (SC) equations.

Table 4. Lag Order Selection Criteria

\begin{tabular}{ccccccc}
\hline Lag & LogL & LR & FPE & AIC & SC & HQ \\
\hline 0 & -45.239 & NA & 0.004 & 3.014 & 3.152 & 3.060 \\
1 & 135.509 & 316.310 & $8.95 \mathrm{e}-08$ & -7.719 & -7.169 & -7.537 \\
2 & 171.063 & $55.5522^{*}$ & $1.73 \mathrm{e}-08^{*}$ & $-9.378^{*}$ & $-8.417^{*}$ & $-9.060^{*}$ \\
3 & 177.339 & 8.6299 & $2.15 \mathrm{e}-08$ & -9.208 & -7.834 & -8.753 \\
\hline
\end{tabular}

*Indicates lag order selected by the criterion

LR: sequential modified LR test statistic (each test at $5 \%$ level)

FPE: Final prediction error

AIC: Akaike information criterion

SC: Schwarz information criterion

HQ: Hannan-Quinn information criterion

Cointegration relationships can only be formed by variables that are integrated to the same degree. The results of testing the optimum lag length on the times series data 
presented in Table 4 report that the optimal lag criterion in the data is lag two. This can be seen from the LR, FPE, AIC, SC, and HQ criteria, which show statistically supports lag two if these variables are tested with a lag distribution model.

\section{Cointegration test}

The next stage is cointegration testing using the Augmented Dickey-Fuller (ADF) method, and this is to obtain long-run relationships between variables in the modeling. This test is done as a start to avoid false regression. If the linear combination between variables is stationary or $\mathrm{r}=\mathrm{I}(0)$. This means that although the variables used are not stationary, these variables tend to be in equilibrium in the long run. Therefore, the linear combination of these variables is called cointegration regression, and the resulting parameters are referred to as long-run coefficients. The cointegration test results presented in Table 5 show that the variables of economic growth, electricity consumption, and carbon dioxide emissions in Indonesia are cointegrated from the two tests through Trace and Max-Eigen. The results of the cointegration test are presented in Table 5.

In the 1985-2019 period, the three variables of life expectancy, economic growth, and air pollution in Indonesia have a long-run balance. The trace statistic test indicated that the three equations had cointegration at a significance level of 5 percent. Meanwhile, the Max-Eigen statistical test also shows that three equations are cointegrated at a significance level of 5 percent.

Table 5. Johansen cointegration test

\begin{tabular}{ccccccc}
\hline Hypothesis & Trace test & $\begin{array}{c}\text { Critical } \\
\text { value }\end{array}$ & Prob.** & Max-Eigen test & $\begin{array}{c}\text { Critical } \\
\text { value }\end{array}$ & Prob.** $^{* *}$ \\
\hline$r=0^{*}$ & 33.754 & 29.797 & $0.016^{*}$ & 16.409 & 21.131 & 0.201 \\
$r \leq 1$ & 17.344 & 15.494 & $0.026^{*}$ & 11.334 & 14.264 & 0.138 \\
$r \leq 2^{*}$ & 6.011 & 3.841 & $0.014^{*}$ & 6.010 & 3.841 & $0.014^{*}$ \\
\hline
\end{tabular}

Trace and Max-eigenvalue test indicates one cointegrating eq(s) at the 0.05 level; *Denotes rejection of the hypothesis at the 0.05 level; ** MacKinnon-Haug-Michelis (1999) p-values

\section{The ARDL Model Estimation Results}

Table 6 presented shows that air pollution $\left(\mathrm{CO}_{2}\right.$ emissions) negatively has a significant effect on life expectancy in the long run, where a 1 percent increase in air pollution in the current period would reduce future life expectancy by -0.071 while keeping other factors constant. Meanwhile, economic growth has a positive sign and significantly influences life expectancy. Economic growth that increases by 1 percent today will increase life expectancy in the future by 0.014 while keeping everything else constant.

The negative and statistically significant estimate for $\mathrm{ECM}_{\mathrm{t}-1}$ of -0.656 provides strong evidence of a long-run relationship between series in the Indonesian case. The 
coefficients are statistically significant at the 5 percent level and reveal that the shortrun deviation is corrected by 5 percent towards the long-run equilibrium path each year. The empirical model also passed major diagnostic tests. Diagnostic tests revealed that the short-run model error terms were normally distributed and free from serial correlation and heteroscedasticity. The functional form of the short-run model is also well defined, as revealed by the Ramsey reset test. We also provide an approximate stability test of the ARDL limit test using the CUSUM test. The results illustrated in Figure 2 show that the CUSUM statistical plot is within the critical limit.

Table 6. The selected ARDL model result

\begin{tabular}{|c|c|c|c|c|}
\hline \multicolumn{5}{|c|}{$\begin{array}{l}\text { Dependent Variable = InLE } \\
\text { Long-run results }\end{array}$} \\
\hline Variable & Coefficient & SE. & t-Stat & Prob.* \\
\hline Constant & 3.691 & 0.921 & 4.007 & 0.000 \\
\hline $\mathrm{InCO}_{2}$ & -0.071 & 0.004 & -17.755 & 0.000 \\
\hline InGDP & 0.014 & 0.003 & 4.667 & 0.000 \\
\hline $\mathrm{R}^{2}$ & 0.8590 & & & \\
\hline F-stat & 63.168 & & & \\
\hline \multicolumn{5}{|l|}{ Short-run results } \\
\hline Variable & Coefficient & SE. & t-Stat & Prob.* \\
\hline Constant & 2.822 & 0.482 & 5.850 & 0.000 \\
\hline$\Delta \mathrm{lnCO}_{2}$ & -0.325 & 0.131 & -2.494 & 0.019 \\
\hline$\triangle \mathrm{lnGDP}$ & -0.130 & 0.023 & -5.506 & 0.000 \\
\hline$\Delta \operatorname{lnLE}_{\mathrm{t}-1}$ & 0.940 & 0.016 & 6.288 & 0.000 \\
\hline $\mathrm{ECM}_{\mathrm{t}-1}$ & 0.656 & 0.174 & 3.763 & 0.008 \\
\hline $\mathrm{R}^{2}$ & 0.9485 & & & \\
\hline F-stat & 16.056 & & & \\
\hline Diagnostic tests & F-stat & & & \\
\hline Serial correlation & $5.393(0.642)$ & & & \\
\hline Heteroscedasticity & $4.123(0.389)$ & & & \\
\hline Normality & $0.929(0.628)$ & & & \\
\hline Ramsey reset & 0.731 (0.399) & & & \\
\hline
\end{tabular}

Notes: ${ }^{* *} 1 \%,{ }^{* *} 5 \%$ and $* 10 \%$ at significant levels respectively.

Figure 2 shows the Cumulative Sum of Recursive Residual (CUSUM) stability test, which shows that the model used is stable because the CUSUM line is still between the 5 percent significant line. Thus, the stability of life expectancy is affected by changes in air pollution and economic growth in Indonesia. 
Figure 2. Recursive Cumulative Residual Sum Plot. The straight line represents the critical limit at the significance level of 5 percent.

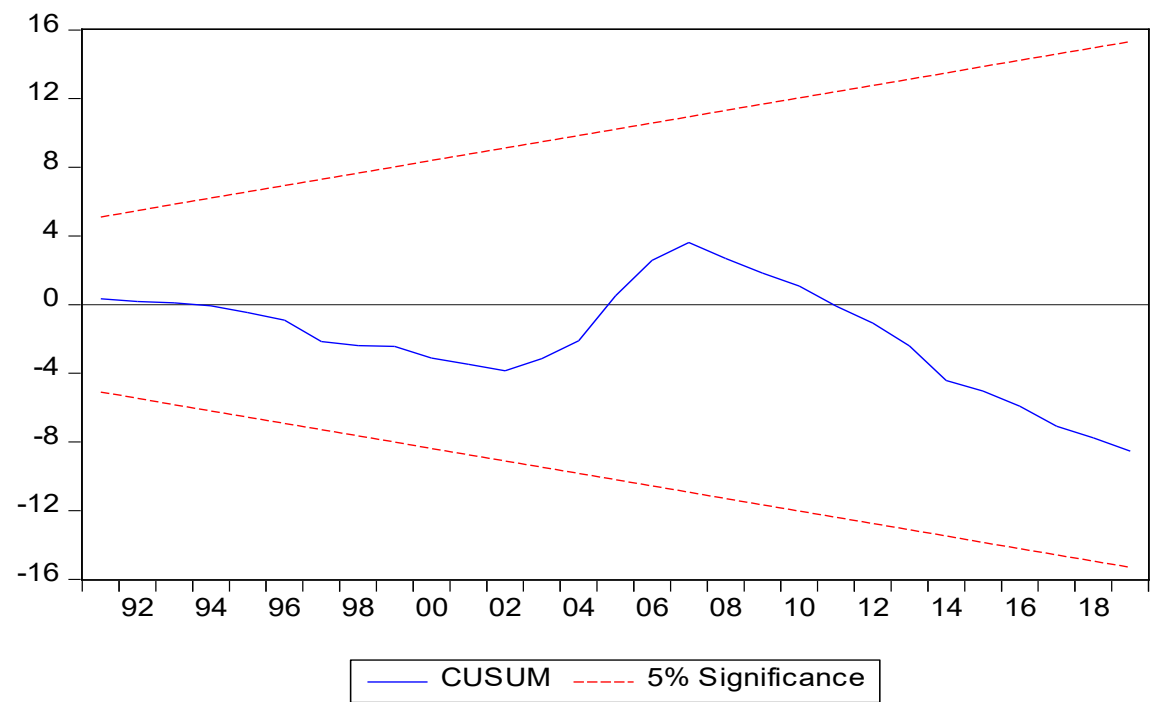

\section{The VECM Granger Causality Estimation Results}

The existence of a long-run relationship (cointegration) between variables such as air pollution, economic growth, and life expectancy encourages us to apply Granger's VECM causality approach, which provides information about causality between variables for both the long and short-run. Therefore, accurate information about the direction of causality between variables helps policymakers to have a clear picture of the issue, enabling interested parties to formulate health and economic policies to improve the environmental quality of an area, at the same time being able to promote sustainable economic growth to maintain a high standard of living over the long-run.

Table 7 reports the results of the Granger causality test. Long-run causality is indicated by the significance of the coefficient of the error correction term lagging one period ECT $\mathrm{t}_{\text {- }}$ ${ }_{1}$ in equation $(2,3,4)$ using the t-test. Short-run causality can be detected by the joint significance of the LR test of the lagging explanatory variable in the equation. Our empirical results show that $\mathrm{ECT}_{\mathrm{t}-1}$ has a negative sign and is statistically significant in all VECM equations. Long-run causality results reveal that feedback effects are found between economic growth, air pollution, and life expectancy. The relationship between economic growth and air pollution is two-way. Likewise, a two-way causality was found between air pollution and life expectancy. Granger's economic growth led to life expectancy, but the same was not valid for the opposite side. Based on the results of short-run Granger causality estimates, there is evidence of a two-way relationship between air pollution and life expectancy at a significance level of 5 percent. This study also found evidence of a two-way relationship between economic growth and air pollution at a significance level of 5 percent. In addition, there is evidence of a unidirectional relationship of economic growth with life expectancy at a significance level of 5 percent. The cointegration estimation results in the equation show evidence of a long-run relationship between life expectancy, economic growth, and air pollution at a significance level of 5 percent. 
Table 7. VECM Granger Causality test

\begin{tabular}{|c|c|c|c|c|}
\hline \multirow{3}{*}{ Dependent Variable } & \multicolumn{3}{|c|}{ Causality test } & \multirow{3}{*}{$\begin{array}{l}\text { Log-run } \\
\text { ECT }_{t-1}\end{array}$} \\
\hline & \multicolumn{3}{|c|}{ Short-run } & \\
\hline & $\Sigma \Delta \operatorname{lnLE}{ }_{t-1}$ & $\Sigma \Delta \operatorname{lnCO}{ }_{2 t-1}$ & $\Sigma \Delta \operatorname{lnGDP}{ }_{\mathrm{t}-1}$ & \\
\hline$\Delta \operatorname{lnLE}{ }_{t}$ & - & $\begin{array}{l}5.592^{* *} \\
(0.042)\end{array}$ & $\begin{array}{c}13.088^{* * *} \\
(0.001)\end{array}$ & $\begin{array}{c}-0.571^{* * *} \\
{[-4.276]}\end{array}$ \\
\hline$\Delta \mathrm{InCO}_{2 t}$ & $\begin{array}{c}11.177^{* *} \\
(0.003)\end{array}$ & - & $\begin{array}{l}5.103^{* *} \\
(0.059)\end{array}$ & $\begin{array}{c}-4.182^{* *} \\
{[-5.361]}\end{array}$ \\
\hline$\Delta \operatorname{lnGDP}{ }_{t}$ & $\begin{array}{c}2.804 \\
(0.2461)\end{array}$ & $\begin{array}{l}5.519^{* *} \\
(0.045)\end{array}$ & - & $\begin{array}{c}-1.751^{* * *} \\
{[-3.686]}\end{array}$ \\
\hline
\end{tabular}

Note: ${ }^{*} 10 \%,{ }^{* *} 5 \%$ and ${ }^{* * *} 1 \%$ at significant levels respectively; ( ) probability; [ ] t-stat

\section{Relationship between Air Pollution and Life Expectancy}

The study findings provide strong evidence that air pollution negatively and significantly affects life expectancy. This finding is in line with the study by Ebenstein et al. (2015). The two-way relationship between environmental pollution has attracted the interest of many economists and researchers. Air pollution is one of the core elements of the environment, and if air pollution increases, it affects human health by affecting metabolism. Various studies have similar results that high air pollution increases mortality, and there is a positive relationship between mortality and air pollution (Tran et al., 2018; Wang et al., 2020).

Additionally, the study conducted by Varabyova \& Müller (2016); Chaabouni \& Saidi (2017) showed similar results, proving that high air pollution increases mortality and has a negative relationship with carbon emissions or air pollution. The use of a time series model for this type of data is that the results can be biased from factors such as temperature and influenza epidemics, which are susceptible to variation over a short period (Goenka et al., 2012). As a result, more recent studies have analyzed the relationship between air pollution and life expectancy as a measure of overall public health, as annual comparisons aggregate life expectancy.

Other supporting studies have also been carried out by (Mariani et al., 2010), who found a positive correlation between life expectancy and environmental quality, both in the long run and along the transition path. These results are consistent with stylistic facts relating to life expectancy and environmental performance measures. The study by Agbanike et al. (2019) found that carbon dioxide $\left(\mathrm{CO}_{2}\right)$ emissions on life expectancy in Nigeria were harmful and more robust in the long run. The study conducted by Kelly (2017) found a negative relationship between average exposure to air pollution and life expectancy for cases in 111 countries. Furthermore, Lelieveld et al. (2020) found that air pollution harms life expectancy in Europe and East Asia. Average Global life expectancy loss from air pollution dramatically exceeds that figure by force (all forms together), that is, by order of magnitude (Loss of life expectancy 2.9 and 0.3 years, respectively). 


\section{Relationship between Economic Growth and Air Pollution}

The findings in the study prove that there is a two-way relationship between economic growth and air pollution. In theory, economic growth means an increase in actual output created from production and consumption activities, these activities are believed to produce waste and pollution that cannot be reused for further production, consumption, and distribution activities, which are then disposed of into water, air, and soil that cause the environment in an area to be damaged and polluted, this causes the health of the population to be less well maintained. A recent study on the relationship between economic growth, pollution, and life expectancy conducted by Ebenstein et al. (2015) found a strong positive relationship between GDP and life expectancy. A doubling of income is expected to increase life expectancy by 3.5 years and reduce 121 deaths per 100,000. The study by Kunze (2014) found that an increase in life expectancy reduces economic growth without policy innovation. The relationship between the two is in the form of an inverted-U. In addition, the study by Jiang et al. (2020) found regional differences in the relationship between air pollution and economic growth in the two countries. In both countries, an inverted U-shaped pattern was found in the metropolitan area, while in the non-metropolitan area, an inverted U-shaped pattern.

\section{Relationship between Economic Growth and Life Expectancy}

The findings by applying the ARDL model show that economic growth has a positive and significant impact on life expectancy. This evidence is quite strong because it is supported by several studies conducted by Weil (2014). His findings suggest a two-way relationship between health and economic growth. On the other hand, the research conducted by Andrew et al. (2015) found that slower reductions in pollution concentrations only increased average life expectancy by 0.35 years. This visit has implications for public health because reducing air pollution can reduce overall mortality. The health consequences of pollution in developing countries are difficult to isolate because income growth often coincides with increases in air pollution (Ebenstein et al., 2015). Various literature by Ebenstein et al. (2015), Kunze (2014), and Jiang et al. (2020) found that there is a strong positive relationship between GDP and life expectancy. A doubling of income is expected to increase life expectancy, but in the absence of policy innovation, the relationship between the two is an inverted U-shape. Recently, a study conducted by Sharma (2018) examined the impact of health (proxied by life expectancy) on economic growth in 17 developed countries. Using the general method of moments and macroeconomic data, he concludes the significant overall impact of health, human capital, education (proxied by schools) on economic growth.

Additionally, the study by Cervellati \& Sunde (2011) examined the relationship between life expectancy and economic growth for the period 1940-2000 and found that the effect of changes in life expectancy was different at each stage of the demographic 
transition. Ngangue \& Manfred (2015) investigate the impact of life expectancy on Gross National Income per capita growth in developing countries. The study found a positive relationship between life expectancy and economic growth. Increased life expectancy has a positive impact on growth in developing countries. However, the results are mixed when classifying developing countries according to their income level because the effect is insignificant in middle-income countries.

\section{CONCLUSION}

The application of the ARDL model found evidence that in the long run, air pollution ( $\mathrm{CO}_{2}$ emissions) negatively and has a significant effect on life expectancy. Meanwhile, economic growth has a positive sign and significantly influences life expectancy. In the short run, it is evident that the current life expectancy is positively and significantly influenced by the life expectancy of the previous period. Air pollution has a negative sign and a significant effect on life expectancy, and then economic growth negatively and significantly affects life expectancy. The results of Granger causality estimation in the short run found evidence of a two-way relationship between air pollution and life expectancy. Other evidence exists of a two-way relationship between economic growth and air pollution. In addition, evidence of a unidirectional relationship from economic growth to life expectancy. The cointegration estimation results in the equation show evidence of a long-run relationship between life expectancy, economic growth, and air pollution at a significance level of 5 percent.

The findings of this study provide direction for policymakers, showing how pollution reduction policies promote economic growth by improving public health by reducing air pollution-related diseases. The policy implication is that air pollution reduction can be achieved by replacing conventional energy sources with renewable energy sources. Policymakers and stakeholders Together play a role in this by encouraging less polluting energy resources. This can be done by imposing a tax on air-polluting companies, reducing air pollution in the environment, and increasing life expectancy.

\section{ACKNOWLEDGMENT}

Thanks to Universitas Sriwijaya for funding support for the 2021 science and technology research scheme with contract number No. 0192/UN9/SB3.LP2M. PT/2021 dated August 16, 2021.

\section{REFERENCES}

Agbanike, T. F., Nwani, C., Uwazie, U. I., Uma, K. E., Anochiwa, L. I., Igberi, C. O., Enyoghasim, M. O., Uwajumogu, N. R., Onwuka, K. O., \& Ogbonnaya, I. O. (2019). Oil, environmental pollution, and life expectancy in Nigeria. Applied Ecology and Environmental Research, 17(5), 11143-11162. https://doi.org/10.15666/ aeer/1705_111 4311162 
Andrew, C., Pope, C. A., Dockery, D. W., Wang, Y., Ezzati, M., \& Francesca, D. (2015). The Effect of Air Pollution Control on Life Expectancy in the United States: An Analysis of 545 US counties from 2000 to 2007. Journal of Investigative Dermatology, 135(2), 612-615. https://doi.org/10.1097/EDE.0b013e3182770237.

Anil Cabraal, R., Barnes, D. F., \& Agarwal, S. G. (2005). Productive uses of energy for rural development. Annual Review of Environment and Resources, 30, 117-144.

Bahmani-Oskooee, M., \& Brooks, T. J. (2003). New criteria for selecting the optimum lags in Johansen's cointegration technique. Applied Economics, 35(8), 875-880. https://doi. org/10.1080/00036840210129419

Bashir, A., Susetyo, D., Suhel, S., \& Azwardi, A. (2021). Relationships between Urbanization, Economic Growth, Energy Consumption, and CO2 Emissions: Empirical Evidence from Indonesia. Journal of Asian Finance, Economics, and Business, 8(3), 79-90. https://doi.org/10.13106/jafeb.2021.vol8.no3.0079

Bashir, A., Thamrin, K. M. H., Farhan, M., Mukhlis, \& Atiyatna, D. P. (2019). The Causality between Human Capital, Energy Consumption, CO2 Emissions, and Economic Growth: Empirical Evidence from Indonesia. International Journal of Energy Economics and Policy, 9(2), 98-104. https://doi.org/10.32479/ijeep.7377

Biyase, M., \& Maleka, M. (2019). Life Expectancy and Economic Growth: Evidence from the Southern African Development Community. International Economics, 72(3), 351-366.

Carson, R. T., Jeon, Y., \& McCubbin, D. R. (1997). The relationship between air pollution emissions and income: US data. Environment and Development Economics, 2(4), 433-450. https://doi.org/10.1017/S1355770X97000235

Cervellati, M., \& Sunde, U. (2011). Life expectancy and economic growth: The role of the demographic transition. Journal of Economic Growth, 16(2), 99-133. https:// doi.org/10. 1007/s10887-011-9065-2

Cesur, R., Tekin, E., \& Ulker, A. (2017). Air Pollution and Infant Mortality: Evidence from the Expansion of Natural Gas Infrastructure. Economic Journal, 127(600), 330-362. https://doi.org/10.1111/ecoj.12285

Chaabouni, S., \& Saidi, K. (2017). The dynamic links between carbon dioxide (CO2) emissions, health spending and GDP growth: A case study for 51 countries. Environmental Research, 158, 137-144. https://doi.org/10.1016/j.envres.2017. 05.041

De Sherbinin, A., Carr, D., Cassels, S., \& Jiang, L. (2007). Population and Environment. Annu Rev Environ Resour, 32, 345-373. https://doi.org/10.1146/annurev.energy.32. 041306.100243.Population

Dholakia, H. H., Bhadra, D., \& Garg, A. (2014). Short-term association between ambient air pollution and mortality and modification by temperature in five Indian cities. Atmospheric Environment, 99, 168-174. https://doi.org/10.1016/j. atmosenv.2014.09. 071 
Ebenstein, A., Fan, M., Greenstone, M., He, G., Yin, P., \& Zhou, M. (2015). Growth, Pollution, and Life Expectancy: China from 1991-2012. American Economic Review: Papers \& Proceedings, 105(5), 226-231. https://doi.org/10.1257/aer. p20151094

Engle, R. F., \& Granger, C. W. J. (1987). Co-Integration and Error Correction: Representation, Estimation, and Testing. Econometrica, 55(2), 251-276. https://doi. org /10.2307/1913236

Fauzi, R. (2017). Effects of Energy Consumption, Forest Areas and Economic Growth toward CO2 emissions in 6 (six) ASEAN Member Countries: A Panel Data Analysis Approach. Ecolab, 11(1), 1-52.

Ghanem, S. K. (2018). Using a multi-equation model, the relationship between population and the environment and its impact on sustainable development in Egypt. Environment, Development, and Sustainability, 20, 305-342. https://doi.org/10.1007/ s10668-0169882-8

Goenka, A., Jafarey, S., \& Pouliot, W. (2012). Pollution, Mortality and Optimal Environmental Policy. In Discussion Paper Series (pp. 1-44). Department of Economics, City University of London.

Harris, J. M., Roach, B., \& Codur, A.-M. (2017). The Economics of Global Climate Change. In Global Development And Environment Institute, Medford, MA 02155, Tufts University (pp. 1-67).

He, L., \& Li, N. (2019). The threshold effect of longevity: life expectancy and economic growth. Applied Economics Letters, 26(14), 1210-1213. https://doi.org/10.1080/ 13504851.2018 .1543932

Jiang, M., Kim, E., \& Woo, Y. (2020). The relationship between economic growth and air pollution-A regional comparison between China and South Korea. International Journal of Environmental Research and Public Health, 17(8), 11-14. https://doi. org/10.3390/ ijerph17082761

Kaygusuz, K. (2007). Energy for Sustainable Development: Key Issues and Challenges. Energy Sources: Economics, Planning, and Policy, 2(1), 73-83. https://doi.org/10. 1080/15567240500402560

Kelly, Z. (2017). Air pollution and life expectancy. In Sacred Heart University Scholar (Vol. 1, Issue Article 2, pp. 2-10).

Kunze, L. (2014). Life expectancy and economic growth. Journal of Macroeconomics, 39, 54-65. https://doi.org/10.1016/j.jmacro.2013.12.004

Lelieveld, J., Pozzer, A., Pöschl, U., Fnais, M., Haines, A., \& Münzel, T. (2020). Loss of life expectancy from air pollution compared to other risk factors: A worldwide perspective. Cardiovascular Research, 116(11), 1910-1917. https://doi.org/10.1093/ $\mathrm{cvr} / \mathrm{cvaa} 025$

Manisalidis, I., Stavropoulou, E., Stavropoulos, A., \& Bezirtzoglou, E. (2020). Environmental 
and Health Impacts of Air Pollution: A Review. Frontiers in Public Health, 8(14), 1-13. https://doi.org/10.3389/fpubh.2020.00014

Mansor, M., \& Harun, N. Z. (2014). Health Issues and Awareness, and the Significant of Green Space for Health Promotion in Malaysia. Procedia - Social and Behavioral Sciences, 153, 209-220. https://doi.org/10.1016/j.sbspro.2014.10.055

Mariani, F., Pérez-Barahona, A., \& Raffin, N. (2010). Life expectancy and the environment. Journal of Economic Dynamics and Control, 34(4), 798-815. https://doi.org/10.1016/j. jedc. 2009.11 .007

Misra, A. K. (2014). Climate change and challenges of water and food security. International Journal of Sustainable Built Environment, 3(1), 153-165. https://doi. org/10.1016/j.ijsbe. 2014.04.006

Ngangue, N., \& Manfred, K. (2015). The Impact of Life Expectancy on Economic Growth in Developing Countries. Asian Economic and Financial Review Journal, 5(4), 653-660.

Okunade, A. A., \& Osmani, A. R. (2020). Effects of life expectancy on economic growth: new results using the flexible Box-Cox power transformation model. Applied Economics Letters, 27(20), 1681-1684. https://doi.org/10.1080/13504851.2020.17 13976

Olivier, J. G. J., Janssens-Maenhout, G., Muntean, M., \& Peters, J. A. H. W. (2016). Trends in Global CO² Emissions: 2016 Report. PBL Netherlands Environmental Assessment Agency \& European Commission's Joint Research Centre (JRC).

Parrique, T., Barth, J., Briens, F., Kerschner, C., Kraus-Polk, A., Kuokkanen, A., \& Spangenberg, J. H. (2019). Decoupling debunked: Evidence and arguments against green growth as a sole strategy for sustainability. In European Environmental Bureau (Issue July). www.eeb.org

Patz, J. A., Githeko, A. K., McCarty, J. P., Hussein, S., Confalonieri, U., \& De Wet, N. (2003). Climate change and infectious diseases. In A. J. McMichael, D. H. Campbell-Lendrum, C. F. Corvalán, K. L. Ebi, A. K. Githeko, J. D. Scheraga, \& A. Woodward (Eds.), Climate Change and Human Health: Risks and Responses (pp. 103-127). World Health Organization. https://doi.org/10.2307/ 2137486

Perrino, C., Gilardoni, S., Landi, T., Abita, A., Ferrara, I., Oliverio, S., Busetto, M., Calzolari, F., Catrambone, M., Cristofanelli, P., Dalla Torre, S., Esposito, G., Giusto, M., Mosca, S., Pareti, S., Rantica, E., Sargolini, T., Tranchida, G., \& Bonasoni, P. (2020). Air Quality Characterization at Three Industrial Areas in Southern Italy. Frontiers in Environmental Science, 7(196), 1-18. https://doi.org/10.3389/ fenvs.2019.00196

Rjoub, H., Odugbesan, J. A., \& Adebayo, T. S. (2021). Investigating the Causal Relationships among Carbon Emissions, Economic Growth, and Life Expectancy 
in Turkey: Evidence from Time and Frequency Domain Causality Techniques. Sustainability, 13, 2924. https://doi.org/10.3390/su13052924

Santika, T., Meijaard, E., Budiharta, S., Law, E. A., Kusworo, A., Hutabarat, J. A., Indrawan, T. P., Struebig, M., Raharjo, S., Huda, I., Ekaputri, A. D., Trison, S., Stigner, M., \& Wilson, K. A. (2017). Community forest management in Indonesia: Avoided deforestation in the context of anthropogenic and climate complexities. Global Environmental Change, 46, 60-71. https://doi.org/10.1016/j.gloenvcha.2017. 08.002

Schraufnagel, D. E., Balmes, J. R., de Matteis, S., Hoffman, B., Kim, W. J., Perez-Padilla, R., Rice, M., Sood, A., Vanker, A., \& Wuebbles, D. J. (2019). Health benefits of air pollution reduction. Annals of the American Thoracic Society, 16(12), 1478-1487. https://doi.org/10.1513/AnnalsATS.201907-538CME

Selden, T. M., \& Song, D. (1994). Environmental Quality and Development: Is There a Kuznets Curve for Air Pollution Emissions?. Journal of Environmental Economics and Management, 27(2), 147-162. https://doi.org/10.1006/JEEM.1994.1031

Selden, T. M., \& Song, D. (1995). Neoclassical growth, the J curve for abatement, and the inverted $U$ curve for pollution. Journal of Environmental Economics and Management, 29(2), 162-168. https://doi.org/10.1006/jeem.1995.1038

Sharma, R. (2018). Health and Economic Growth: Evidence from Dynamic Panel Data of 143 Years. PLoS ONE, 13(10), 1-20. https://doi.org/10.1371/journal.pone. 0204940

Tran, H., Kim, J., Kim, D., Choi, M., \& Choi, M. (2018). Impact of air pollution on cause-specific mortality in Korea: Results from Bayesian Model Averaging and Principle Component Regression approaches. Science of the Total Environment, 636, 1020-1031. https://doi.org/10.1016/j.scitotenv.2018.04.273

Varabyova, Y., \& Müller, J. M. (2016). The efficiency of health care production in OECD countries: A systematic review and meta-analysis of cross-country comparisons. Health Policy, 120(3), 252-263. https://doi.org/10.1016/j.healthpol. 2015.12.005

Wang, S., Gao, S., Li, S., \& Feng, K. (2020). Strategizing the relation between urbanization and air pollution: Empirical evidence from global countries. Journal of Cleaner Production, 243, 118615. https://doi.org/10.1016/j.jclepro.2019.118615

Weil, D. N. (2014). Health and Economic Growth. In Aghion, P., \& Durlauf, S (Eds). Handbook of Economic Growth, 2B, 623-682. Elsevier BV https://doi.org/10.1016/ B978-0-444-53540-5.00003-3

Zou, X., Wang, F., Chang, Y., Zhao, L., \& Zheng, W. (2018). Two-level multi-block operating performance optimality assessment for plant-wide processes. Canadian Journal of Chemical Engineering, 96(11), 2395-2407. https://doi.org/10.1002/ cjce. 23159 
Zou, X., Zhao, C., \& Gao, F. (2020). Linearity Decomposition-Based Cointegration Analysis for Nonlinear and Nonstationary Process Performance Assessment. Industrial and Engineering Chemistry Research, 59(7), 3052-3063. https://doi.org/10.1021/ acs. iecr.9b05600 